\title{
APLIKASI DATA ENVELOPMENT ANALYSIS UNTUK MENELAAH EFISIENSI BIAYA DAN PENDAPATAN PERUSAHAAN (STUDI KASUS PT.DIAN SWARA)
}

\author{
Ari Binuko ${ }^{* 1}$, Hermanto Siregar ${ }^{* *}$, dan Sri Hartoyo***) \\ *) Universitas Pembangunan Nasional "Veteran" Jakarta \\ Jl. Rs. Fatmawati, Pondok Labu, Jakarta Selatan, DKI Jakarta, 12450 \\ **) Departemen Ilmu Ekonomi, Fakultas Ekonomi Dan Manajemen, Institut Pertanian Bogor \\ Gedung FEM Lt. 2 Jl. Kamper, Kampus IPB Dramaga Bogor 16680
}

\begin{abstract}
The research is to evaluate the cost efficiency level and the income of Dian Swara a company in Purwokerto, Central Java. The data is analyzed using DEA (Data Envelopment Analysis) with CRS (Constant Return of Scale) method and as the input is the operational cost, administration cost and marketing cost while the output is the event income, program syndicate income and advertisement income. The first step in this research is calculating the efficiency value cost and income, also the independent variable consist of ROA (Return of Asset), ROE (Return of Equity), aging of receivables, DER (Debt to Equity Ratio) and dummy. The next step is to observe the impact of the independent variables toward the efficiency using multiple linear regression analysis. The result using DEA shows that the efficiency value from 2009-2014 did not reach 1. The most efficient is in 2013 where the value was 0.98 and the least efficient was in 2012 the value was 0.71 . Whereas the result from the multiple linear regression analysis shows that ROA and ROE has a positive and significant impact in efficiency.
\end{abstract}

Keywords: dian swara, CSR, DEA, ROA, ROE

\begin{abstract}
ABSTRAK
Penelitian ini untuk mengukur tingkat efisiensi biaya dan pendapatan pada perusahaan Dian Swara yang berada di Purwokerto, Jawa Tengah. Menggunakan DEA (Data Envelopment Analysis) dengan metode CRS (Constant Return of Scale) dan sebagai input adalah biaya operasional, biaya administrasi serta biaya pemasaran. Yang digunakan sebagai output dalam penelitian ini adalah pendapatan event, pendapatan sindikasi program serta pendapatan iklan. Langkah pertama dalam penelitian ini adalah menghitung nilai efisiensi biaya dan pendapatan serta menghitung variabel independennya yang terdiri dari ROA (Return of Asset), ROE (Return of Equity), Umur piutang, DER (Debt to Equity Ratio) serta dummy. Langkah kedua dalam penelitian ini, melihat pengaruh variabel independen terhadap efisiensi dengan menggunakan analisis regresi linear berganda. Hasil dari perhitungan dengan menggunakan DEA menunjukan bahwa nilai efisiensi dari periode tahun 2009 sampai dengan tahun 2014 tidak ada yang mencapai nilai 1.00. Dalam periode tersebut tahun yang paling efisien adalah tahun 2013 dengan nilai 0.98 dan tahun yang inefisien dalam penelitian ini adalah tahun 2012 dengan nilai 0.71. Sedangkan hasil dari analisis regresi menunjukan bahwa ROA dan ROE berpengaruh positif dan signifikan terhadap efisiensi.
\end{abstract}

Kata kunci: dian swara, CSR, DEA, ROA, ROE

\footnotetext{
${ }^{1}$ Alamat Korespondensi:

Email:binuko73@gmail.com
} 


\section{PENDAHULUAN}

Perkembangan industri stasiun radio penyiaran di Indonesia dari tahun ke tahun mengalami peningkatan. Pada akhir tahun 2009, jumlah stasiun radio di Indonesia adalah 1.288 stasiun, terdiri atas 384 AM dan 904 FM (Sumber: Data Stasistik Ditjen Postel Semester II Tahun 2009), di akhir tahun 2014 berkembang menjadi 2.018 stasiun terdiri atas 134 AM dan 1884 FM (Data Statistik Ditjen Postel Semester II, 2013). Secara keseluruhan pertumbuhan radio dari tahun 2009 sampai dengan tahun 2014 sebesar 48\% dengan total pertumbuhan rata-rata $10 \%$ disetiap tahunnya.

Pertumbuhan jumlah radio yang signifikan ternyata tidak berbanding lurus dengan peningkatan jumlah pendengar radio (radio reach) dalam populasi, jumlah lama waktu mendengarkan radio (time spent listening) dan jumlah alokasi belanja iklan radio (RadEx). Data radio reach atau jumlah pendengar radio di kota-kota besar di Indonesia dari tahun 2010 sampai dengan 2014, tidak mengalami pertumbuhan, dari tahun ke tahun (Tabel 1). Demikian juga data time spent listening atau lamanya waktu mendengar dari tahun 2010 sampai dengan tahun 2014 tidak mengalami pertumbuhan, bahkan di kota-kota besar di Indonesia mengalami penurunan berkisar per minggu rata-rata 15,5 jam atau 2,2 jam per hari. Data dari Nielsen menunjukan bahwa, media televisi yang paling signifikan pertumbuhannya dibandingkan dengan media yang lainnya seperti koran, majalah, tabloid, radio serta media outdoor. Pertumbuhannya rata-rata dari tahun 2009 sampai dengan 2014 sebesar 22\%, hal ini berbanding terbalik jika dibandingkan dengan pertumbuhan radio yang hanya $7,3 \%$. Di sisi lain media-media ini yang diperhitungkan di masa digital saat ini. Pertumbuhan rata-rata belanja iklan media (AdEx) dari tahun 2009 sampai dengan 2014 disetiap tahunnya sebesar 19,3\% dan didominasi oleh media televisi dan majalah.

Berbeda dengan belanja iklan radio (RadEx), data menunjukkan bahwa rasio belanja iklan radio (RadEx) terhadap belanja iklan media (AdEx) dari tahun 2009 sampai dengan 2014 rata-rata sebesar $0,9 \%$ dan setiap tahunnya mengalami penurunan. Pertumbuhan rata-rata belanja iklan radio (RadEx) dari tahun 2009 sampai 2014 disetiap tahunnya yang sebesar 7,3\% tidak sebanding dengan pertumbuhan rata-rata jumlah stasiun radio yang mencapai $10 \%$ per tahun. Dapat dipastikan bahwa semakin banyak stasiun radio yang akan memperebutkan belanja iklan yang jumlahnya terbatas dan juga semakin ketat dari tahun ke tahun. Penurunan ini terjadi akibat bergesernya animo pengiklan yang mengalokasikan ke medium lainnya yang dirasakan lebih tepat dan efektif.

PT. Dian Swara merupakan perusahaan swasta murni milik sebuah keluarga. Perusahaan ini melakukan kegiatan perusahaannya dalam bidang radio penyiaran dan event organizer. Selama periode 2009-2014 pendapatanperusahaanmengalamipenurunan, presentase pertumbuhan rata-rata dari tahun ke tahun hanya berkisar $1,3 \%$. Menurunnya pendapatan perusahaan dalam bidang radio penyiaran juga disebabkan oleh persaingan di dalam bisnis jasa penyiaran radio yang ketat dan juga kondisi porsi kue iklan didaerah sangat kecil sehingga berdampak kepada penurunan pendapatan yang diperoleh dari iklan spot. Berdasarkan survei bahwa jumlah stasiun radio swasta di daerah Purwokerto berjumlah enam perusahaan radio yang sejenis. Pendapatan perusahaan dari event juga mengalami penurunan, hal ini disebabkan oleh keadaan krisis ekonomi Eropa dan kebijakan intern baik principle dan agency dari tahun 2012 sampai dengan tahun sekarang. Menurut hasil wawancara dari manajemen PT.Dian Swara, bahwa dengan fenomena tersebut banyak perusahaanperusahaan melakukan cut-off pada seluruh biaya promosi dan juga berubahnya titik penyelenggaraan event yang semula di daerah Purwokerto dan sekitarnya berpindah ke daerah lain. Menurut Kader et al. (2010) dalam penelitiannya mengungkapkan bahwa tidak ada peningkatan secara signifikan efisiensi biaya terhadap kebijakan pemerintah.

Pada Tabel 2 biaya perusahaan mengalami fluktuatif dengan rata-rata pertumbuhannya $0,6 \%$ dari tahun 2009 sampai dengan tahun 2014. Seiring dengan penurunnya pendapatan, biaya perusahaan mengalami kenaikan, hal ini disebabkan oleh tingginya biaya kegiatan off-air dan operasional dan juga langkah dari manajemen didalam menekankan penggunaan modal dan asset untuk mengakselerasi pertumbuhan pendapatan, dalam istilah ekonomi dikatakan dengan capitalintensive. Berdasarkan kondisi tersebut jajaran manajemen juga berusaha melakukan efisiensibiaya-biaya operasionalnya sehingga di masa yang akan datang pendapatan perusahaan dapat terus ditingkatkan. Penelitian yang dilakukan oleh Pinwen (2002) mendefinisikan bahwa mergernya beberapa bank di Taiwan tidak meningkatkan secara signifikan efisiensi biayanya. 
Piutang perusahaan daritahun 2009 sampaidengantahun 2014 cenderung mengalami kenaikan. Periode rata-rata yang diperlukan untuk mengumpulkan piutang adalah 112 hari. Bagi suatu perusahaan jasa, yang mendapat perhatian pertama adalah kemampuan perusahaan di dalam menagih atau mengumpulkan piutangnnya. Semakin besar days receivable, jika perusahaan tidak membuat cadangan terhadap kemungkinan kerugian yang timbul karena tidak tertagihnya piutang, berarti perusahaan telah memperhitungkan labanya terlalu besar. Menurut Sharaf dan Haddad (2015) dalam penelitiaannyamengemukakanbahwaadanyahubungan yang negatif signifikan antara receivable collection period, iventories collection period dan leverage ratio terhadap pendapatan perusahaan. Permasalahan yang dapat dirumuskan dalam penelitian ini adalah bagaimana mengkaji perkembangan komponen-komponen biaya dan pendapatan perusahaan serta faktor-faktor yang Memengaruhi efisiensi biaya dan pendapatan.

Berdasarkan permasalahan maka tujuan dari penelitian ini adalah mengkaji perkembangan komponenkomponen biaya dan pendapatan perusahaan serta faktor-faktor yang memengaruhi efisiensi biaya dan pendapatan. Bagi perusahaan, hasil penelitian ini berguna untuk memberikan gambaran atau informasi bagi manajemen mengenai komponen-komponen biaya dan pendapatan di dalam pengambilan keputusan dengan menggunakan DEA (Data Envelopment Analysis) serta kegunaan penelitian ini adalah untuk melatih kemampuan menganalisis suatu masalah yang dihadapi perusahaan. Sedangkan ruang lingkup penelitian ini dibatasi pada aspek finansial perusahaan dan bersumber dari laporan keuangan perusahaan dari tahun 2009-2014.

Penelitian ini dilakukan pada perusahaan di industri penyiaran radio, yang selama ini belum pernah dilakukan penelitiannya dengan menggunakan DEA. Penelitian yang menggunakan DEA banyak dilakukan pada perusahaan yang bergerak di industri perbankan salah satunya yang dilakukan oleh Nazir dan Alam (2010), Sfinga dan Dimitris (2011), Firdaus dan Hosen (2013) dan penelitian yang dilakukan dalam industri manufaktur salah satunya oleh Abri dan Mahmoudzadeh (2014). Selanjutnya, dalam industri pertanian dan peternakan oleh Sari et al.(2014).

\section{METODE PENELITIAN}

Penelitian ini dilakukan di PT. Dian Swara yang beralamatkan di jalan Gandasuli No. 269 Purwokerto, Jawa Tengah. Periode waktu penelitian dilakukan pada bulan Juli sampai dengan Desember 2015, serta sumber data yang digunakan adalah data laporan keuangan yang terdiri atas laporan rugi laba dan neraca keuangan tahun 2009 sampai dengan tahun 2014 dengan menggunakan jumlah sampel data sebanyak 72 buah. Adapun yang digunakan di dalam penelitian ini sebagai input terdiri atas biaya operasional, biaya administrasi dan biaya pemasaran serta output yang terdiri atas: pendapatan iklan spot, pendapatan event dan pendapatan sindikasi program.

Tabel 1. Pertumbuhan belanja iklan media (AdEx) dan belanja iklan radio (RadEx) di Indonesia dari tahun 2008 sampai 2014 (miliar rupiah)

\begin{tabular}{lccccccc}
\hline \multicolumn{1}{c}{ Expenditure } & 2008 & 2009 & 2010 & 2011 & 2012 & 2013 & 2014 \\
\hline AdEx & 44.492 & 51.081 & 62.685 & 74.538 & 91.053 & 110.879 & 127.910 \\
Growth of AdEx (\%) & & 15 & 23 & 19 & 22 & 22 & 15 \\
RadEx & 559 & 592 & 635 & 671 & 740 & 814 & 854 \\
Growth of RadEx (\%) & & 6 & 7 & 6 & 10 & 10 & 5 \\
Share RadEx (\%) & 1,26 & 1,16 & 1,01 & 0,90 & 0,18 & 0,73 & 0,67 \\
\hline
\end{tabular}

Tabel 2. Kinerja perusahaan PT.Dian Swara tahun 2009 sampai 2014 (juta rupiah)

\begin{tabular}{lcccccc}
\hline & 2009 & 2010 & 2011 & 2012 & 2013 & 2014 \\
\hline Pendapatan & 1.148 & 1.437 & 1.585 & 547 & 560 & 750 \\
Biaya & 1.101 & 1.379 & 1.500 & 492 & 500 & 671 \\
Laba sebelum pajak & 47 & 57 & 85 & 55 & 60 & 79 \\
Pajak & 6 & 7 & 11 & 7 & 7 & 10 \\
Laba bersih & 41 & 50 & 74 & 48 & 52 & 69 \\
Piutang & 285 & 277 & 268 & 177 & 211 & 409 \\
\hline \hline
\end{tabular}


Secara garis besar yang dilakukan dalam penelitian ini adalah menghitung nilai masing-masing variabel independen (ROA, ROE, umur piutang, DER dan dummy) serta menghitung nilai skor/efisiensinya dengan memasukan input dan outputnya. Menghitung efisiensinya menggunakan DEA dengan metode CRS. Setelah diperoleh masing-masing nilai tersebut, diregresi dengan menggunakan analisis regresi linear berganda, seperti yang terdapat pada kerangka pemikiran (Gambar 1).

Dalam penelitian ini langkah-langkah yang dilakukan dalam menganalisis efisiensi biaya dan pendapatan serta menguji pengaruh masing-masing variabel independen terhadap variabel dependen, mengacu pada penelitian Mahdavi et al. (2012) serta Miller dan Noulas (1996) yang menjelaskan adanya hubungan positif antara ROE terhadap efisiensi, yaitu sebagai berikut:

Menghitung besaran nilai ROA (Return On Asset), bahwa analisis rasio yang digunakan dalam penelitian ini berdasarkan pemilihan aspek-aspek yang akan dinilai berdasarkan tujuan analisis, meliputi :

$\mathrm{ROA}=($ Laba operasi $) /($ Rata-rata $)$ aktiva $\times 100 \%$
Rasio ini memperlihatkan perusahaan dalam mengelola modal sendiri secara efektif, mengukur tingkat keuntungan dari investasi yang telah dilakukan pemilik modal sendiri atau pemegang saham (Sawir, 2001).

Return on equity $=($ Laba setelah pajak $) /($ (Rata-rata $)$ modal sendiri) x 100\%

Menghitung nilai rasio perputaran piutang dagang (Receivable Turn Over Ratio) adalah ukuran seberapa kali saldo rata-rata persedian di konversikan ke dalam kas selama tahun tersebut dan dianggap sebagai ukuran efisiensi pemberian kredit dan kebijakan-kebijakan penagihan piutang perusahaan.

Perputaran piutang= Penjualan/ (Rata-rata $\mathrm{x}$ piutang)

Menghitung nilai DER (Debt Equity Ratio). Menurut Sawir (2001) rasio ini menggambarkan perbandingan jumlah hutang dan modal sendiri dalam pendanaan perusahaan dan menunjukan kemampuan modal sendiri untuk memenuhi seluruh kewajibannya. Semakin tinggi rasionya maka semakin besar risiko keuangannya bagi kreditor maupun pemegang saham.

DER $=$ Total kewajiban/Modal sendiri

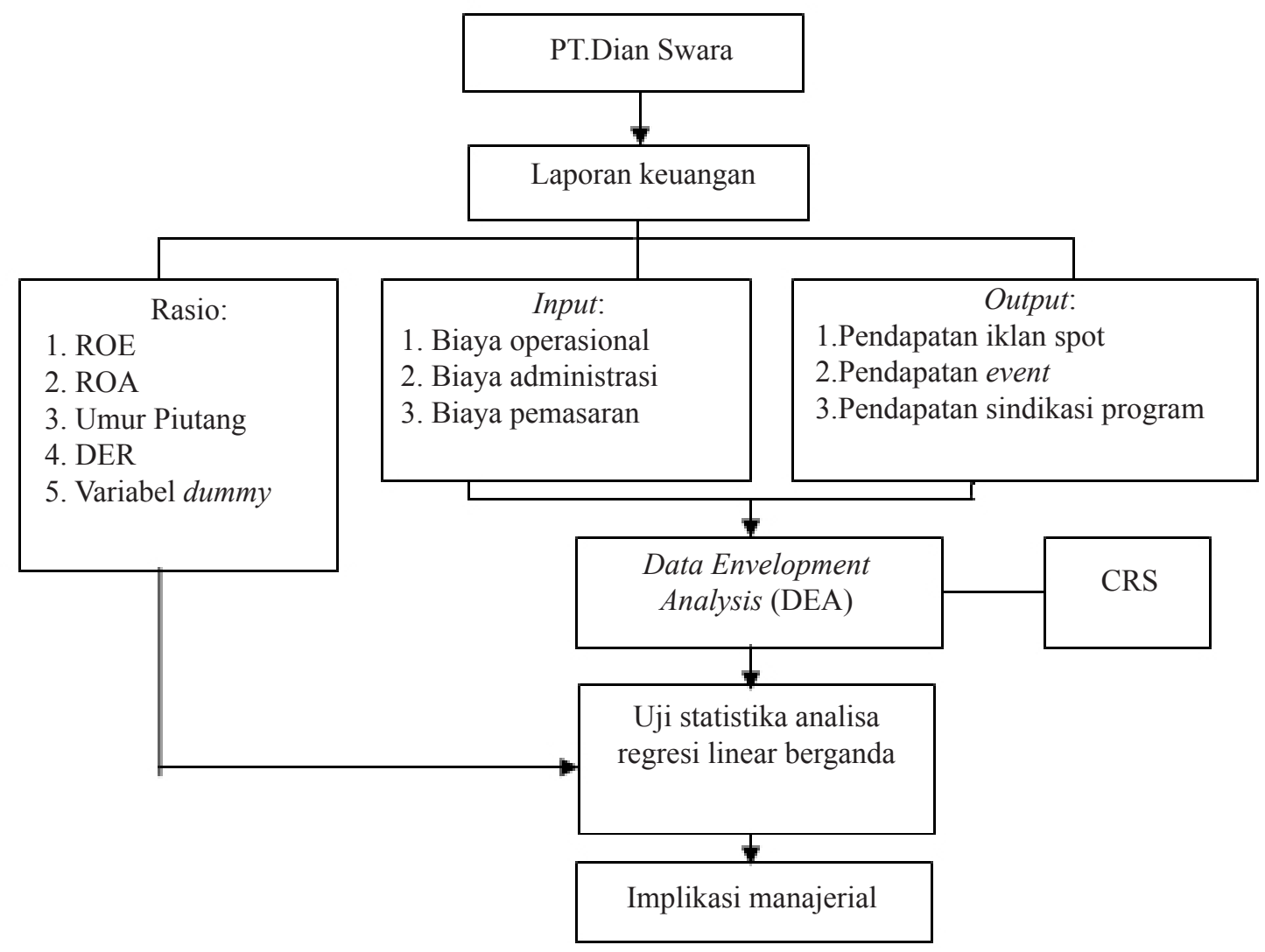

Gambar 1. Kerangka pemikiran penelitian 
Menetapkan variabel dummy, dengan nilai 0 dan 1 . Nilai 0 adalah keadaan sebelum perusahaan melakukan ekspansi bisnis (tahun 2009-2011) dan nilai 1 adalah keadaaan setelah perusahaan melakukan ekspansi bisnis (2012-2014). Langkah selanjutnya adalah menghitung nilai efisiensi dengan menggunakan DEA. Menurut Coelli et al. (2005) menghitung DEA dengan merasiokan seluruh output terhadap seluruh input dengan memasukkan inputnya, yaitu biaya operasional (I1), biaya administrasi (I2) dan biaya pemasaran (I3) dan kemudian sebagai outputnya, yaitu pendapatan iklan spot $(\mathrm{O} 1)$, pendapatan event $(\mathrm{O} 2)$ dan pendapatan sindikasi program (O3). Pada penelitian ini menggunakan tiga input dan tiga output sehingga dapat ditulis persamaan sebagai berikut:

$$
B_{d}=\frac{\sum_{k=1}^{3} \mu_{k} \mathrm{y}_{k 0}}{\sum_{i=1}^{3} \mathrm{v}_{i} \mathrm{x}_{i 0}}
$$

Keterangan :

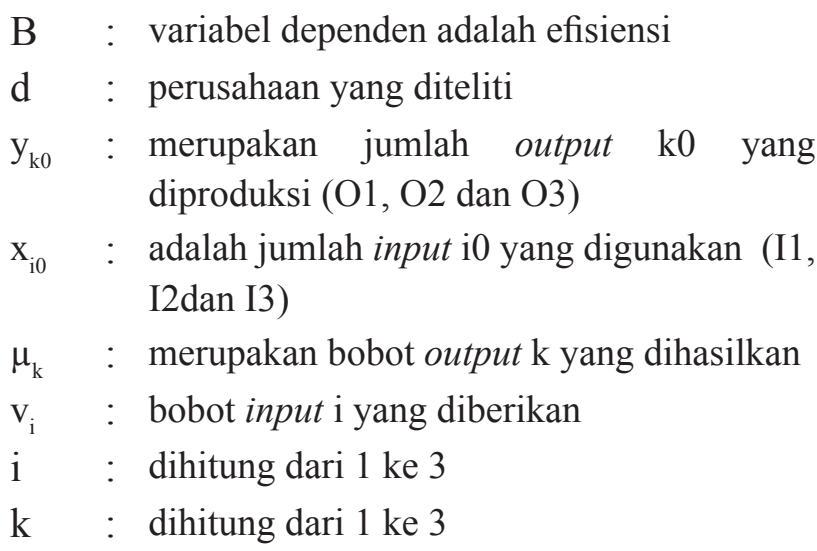

Setelah diperoleh nilai efisiensi maka langkah selanjutnya adalah memodelkan secara matematis persamaan regresi liniear berganda untuk menguji pengaruh variabel bebas terhadap variabel terikatnya dalam hal ini adalah efisiensi, dengan menggunakan metode Ordinary Least Square, berikut adalah persamaan regresi liniear berganda :

$\mathrm{DEA}_{\text {it }}=\beta_{0}+\beta_{1} \mathrm{ROA}_{\mathrm{t}}+\beta_{2} \mathrm{ROE}_{\mathrm{t}}+\beta_{3}$ UmurPiutang $_{\mathrm{t}}+$ $\beta_{4} \mathrm{DER}_{\mathrm{t}}+\beta_{5}$ Dummy $+\mathrm{e}_{\mathrm{t}}$

keterangan :

DEA : tingkat efisiensi

$\beta 0 \quad$ : intercept (konstanta)

$\beta_{1}-\beta_{5}$ : koefisien pengaruh ROA, ROE, Umur Piutang, DER dan dummy

e : error model

t : time (periode 2009-2014)

i : perusahaan

\section{HASIL}

\section{Efisiensi Komponen-komponen Biaya dan Pendapatan}

Hasil pencapaian tingkat efisiensi (Tabel 3) pada perusahaan PT. Dian Swara menunjukkan suatu trend yang fluktuatif, pada periode tersebut tidak ada yang memperoleh nilai efisiensi yang stabil. Tahun 2009 nilai efisiensi terendah terjadi pada bulan Januari sebesar 0,59 . Tahun 2010 nilai efisiensi terendah terjadi pada bulan Februari sebesar 0,86. Tahun 2011 nilai efisiensi terendah terjadi pada bulan Desember sebesar 0,77. Tahun 2012 nilai efisiensi terendah terjadi pada bulan Januari sebesar 0,25. Tahun 2013 nilai efisiensi terendah terjadi pada bulan sebesar 0,90 dan tahun 2014 nilai efisiensi terendah terjadi pada bulan Desember sebesar 0,14 . Hasil penelitian ini sesuai dengan penelitian yang telah dilakukan sebelumnya oleh Sutawijaya dan Lestari (2009), Hartono et al. (2008) yang menggunakan DEA dengan metode CRS.

Tabel 3. Analisis efisiensi dengan metode CRS

\begin{tabular}{lcccccc}
\hline \multicolumn{1}{c}{ Bulan } & 2009 & 2010 & 2011 & 2012 & 2013 & 2014 \\
\hline Januari & 0,59 & 1,00 & 1,00 & 0,25 & 0,90 & 1,00 \\
Februari & 0,86 & 0,86 & 0,91 & 0,31 & 1,00 & 1,00 \\
Maret & 0,93 & 1,00 & 1,00 & 1,00 & 1,00 & 1,00 \\
April & 1,00 & 1,00 & 1,00 & 1,00 & 1,00 & 0,96 \\
Mei & 0,90 & 0,91 & 1,00 & 1,00 & 1,00 & 0,96 \\
Juni & 1,00 & 1,00 & 0,92 & 0,95 & 1,00 & 1,00 \\
Juli & 0,88 & 1,00 & 1,00 & 1,00 & 0,91 & 1,00 \\
Agustus & 1,00 & 0,99 & 0,81 & 0,75 & 1,00 & 0,99 \\
September & 0,72 & 1,00 & 0,88 & 0,80 & 1,00 & 1,00 \\
Oktober & 1,00 & 0,92 & 0,94 & 0,77 & 1,00 & 1,00 \\
November & 1,00 & 1,00 & 0,79 & 0,29 & 0,91 & 0,15 \\
Desember & 0,89 & 0,89 & 0,77 & 0,35 & 1,00 & 0,14 \\
Pencapaian & 0,90 & 0,96 & 0,92 & 0,71 & 0,98 & 0,85 \\
rata-rata & & & & & & \\
\hline
\end{tabular}

Tahun 2013 adalah tahun yang efisien dalam periode penelitian ini, dengan rata-rata nilai efisien sebesar 0,98. Dari hasil perhitungan jumlah output sebesar Rp560.281.260 dan untuk targetnya sebesar Rp568.549.700. Jumlah yang harus ditingkatkan dari sisi output sebesar 1,48\% atau Rp8.268.440, sedangkan untuk jumlah input-nya sebesar Rp500.481.195 dan untuk target efisiensinya sebesar Rp482.340.387 dan jumlah yang harus di reduce dari sisi biaya-biaya sebesar Rp18.140.808 atau 3,62\% dari jumlah input. 
Tahun 2012 adalah tahun yang inefisien artinya perusahaan tidak dapat mengoptimalkan sumber dayanya berupa input dan output secara maksimal, perolehan nilai rata-ratanya efisiensi CRS-nya hanya sebesar 0,71. Dari perhitungan efisiensi dengan metode

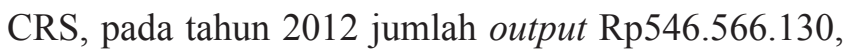
sedangkan target efiensinya Rp707.117.499. Jumlah yang harus ditingkatkan dari sisi pendapatan sebesar 23\% atau Rp160.511.369. Jumlah input Rp491.580.481, sedangkan target efisiensinya Rp336.993.126. Jumlah yang harus di reduce dari sisi biaya-biaya sebesar Rp154.587.355 atau 45\% dari jumlah input.

\section{Faktor-faktor yang Memengaruhi Efisiensi Biaya dan Pendapatan}

Untuk mengetahui faktor-faktor yang memengaruhi efisiensi biaya dan pendapatan perusahaan maka dilakukan terlebih dahulu tahapan didalamnya. Adapun tahapan yang dilakukan adalah pengujian asumsi klasik, analisis variabel independen, analisis statistik deskriptif variabel penelitian dan yang terakhir adalah analisis regresi linear berganda.

\section{Pengujian Asumsi Klasik}

Gejala multikolinieritas ditandai dengan adanya hubungan linieritas yang sangat kuat diantara variabel independen, bahwa masing-masing variabel independen mempunyai nilai variance inflation factor kurang dari 5 sehingga memenuhi asumsi multikolinieritas. Artinya, bahwa tidak terjadi multikolinieritas sedangkan uji autokorelasi menunjukkan nilai probabilitas $(0,1582)$, dimana nilai probabilitas lebih besar dari alpha 5\%, artinya bahwa asumsi tidak terdapat autokorelasi terpenuhi. Sedangkan uji efek heteroskedastisitas diperoleh nilai probabilitas $(0,3074)$, dimana nilai probabilitas lebih besar dari alpha 5\%. Artinya, bahwa asumsi homoskedastisitas terpenuhi.

Analisis variabel independen

Periode 2009 sampai 2011 tingkat pengembalian aktiva (ROA) dan tingkat pengembalian ekuitas (ROE) mengalami suatu penurunan. Pada tahun 2011 perusahaanmemilikitingkatpengembalianaktiva(ROA) yang rendah sebesar $10,42 \%$, keadaan ini dipengaruhi oleh piutang perusahaan yang belum tertagih pada tahun tersebut sehingga berpengaruh terhadap laba dan aktiva. Hal ini didukung oleh hasil penelitian Lazaridis dan Tryfonidis (2006), Raheman dan Nasr (2007) yang menyatakan bahwa tingkat kenaikan dan penurunan perputaran piutang berpengaruh terhadap profitabilitas. Tingkat pengembalian ekuitas (ROE) di tahun 2011 juga mengalami penurunan, hal ini disebabkan ada beberapa kebijakan perusahaan yang belum dilaksanakan pada tahun tersebut. Pada tahun 2012 perusahaan melakukan ekspansi bisnisnya dengan melakukan diversifikasi usahanya dan tingkat pengembalian ekuitas (ROE) sebesar $16,70 \%$, ini dikarenakan ekspansi yang dilakukan perusahaan pada tahun 2012 dapat tercapai dengan baik sehingga berpengaruh terhadap laba. Walaupun jika dibandingkan terhadap laba tahun sebelumnya lebih rendah. Namun, secara pengukuran profitabilitas dianggap sudah cukup baik dikarenakan ada beberapa sasaran yang tercapai.

Total umur piutang usaha dan perputaran piutang usaha dari tahun 2007 sampai dengan 2014 mengalami kenaikan. Umur piutang usaha pada tahun 2009 yang 91 hari, naik menjadi 199 hari di tahun 2014. Hasil perputaran piutang usaha dari tahun 2009 sampai dengan 2014 tidak memperlihatkan perputaran piutang yang tinggi dengan kondisi masih dibawah level 10.

Rasio pertumbuhan DER (Debt to Equity Ratio) periode 2009 sampai 2014 memiliki nilai dibawah 1,00, ini mengindikasikan bahwa perusahaan memiliki hutang yang lebih kecil dari ekuitas yang dimilikinya dan dapat diartikan bahwa operasional perusahaan tidak didanai oleh hutang.

\section{Analisis Statistika Deskriptif Variabel Penelitian}

Nilai minimum ROA adalah 0,1042 , sedangkan nilai maksimum adalah 0,1492 sehingga diperoleh nilai range sebesar 0,0450 , range data relatif kecil hanya $4,5 \%$. Rata-rata ROA sebesar 0,1229 . Variasi data tersebut 0,0002 tercermin dari deviasi yang rendah atau homogen. Nilai minimum ROE adalah 0,1490 sedangkan nilai maksimum adalah 0,2753 sehingga diperoleh nilai range sebesar 0,1263 , range data relatif lebih besar dengan 12,63\%. Rata-rata ROE sebesar 0,1683 . Variasi data tersebut 0,0008 tercermin dari deviasi yang rendah atau homogen. Nilai minimum efisiensi adalah 0,1365 sedangkan nilai maksimum adalah 1,00 sehingga diperoleh nilai range sebesar 0,8635 , range data sangat besar. Rata-rata efisiensi sebesar 0,8853 . Variasi data tersebut 0,0451 tercermin dari deviasi yang tinggi. Nilai minimum DER adalah 0,0303, sedangkan nilai maksimum adalah 0,5177 sehingga diperoleh nilai range sebesar 0,4874 , range 
data sangat besar. Rata-rata DER sebesar 0,3117. Variasi data tersebut 0,0293 tercermin dari deviasi yang tinggi. Nilai minimum umur piutang adalah 62 sedangkan nilai maksimum adalah 199 sehingga diperoleh nilai range sebesar 137, range data sangat besar. Rata-rata umur piutang sebesar 113. Variasi data tersebut 2596 tercermin dari deviasi yang tinggi.

Regresi Liniear Berganda serta Faktor-faktor yang Memengaruhi Efisiensi

Persamaan regresi yang didapat merupakan hasil yang optimal, dari lima variabel independen yang ada, hanya digunakan tiga variabel independen untuk menghasilkan output yang optimal. Pengurangan ini terjadi akibat adanya multikolinieritas antara variabel independen sehingga untuk mendapatkan hasil yang optimal sesuai dengan asumsi klasik maka hanya digunakan tiga variabel independen. Berdasarkan pengolahan data yang dilakukan, hasil regresi linier berganda dapat dilihat pada Tabel 4 .

Tabel 4. Hasil analisis regresi berganda

\begin{tabular}{lcrrr}
\hline \multicolumn{1}{c}{ Variabel } & \multirow{2}{*}{ Coefficient } & $\begin{array}{c}\text { Std. } \\
\text { Error }\end{array}$ & t-Statistic & Prob. \\
\hline ROA & 1,1213 & 0,7679 & 14,4826 & 0,0000 \\
ROE & 0,4811 & 0,2166 & 2,2214 & 0,0263 \\
Dummy & $-0,2879$ & 0,0235 & $-12,2510$ & 0,0000 \\
C & $-0,4389$ & 0,0950 & $-4,6217$ & 0,0000 \\
Efisiensi t-1 & $-0,0224$ & 0,1120 & $-0,2001$ & 0,8414 \\
R-squared & 0,1525 & & & \\
Adjusted & 0,0431 & & & \\
R-squared & & & & \\
F-statistic & 3,3944 & & & \\
Prob & 0,0168 & & & \\
(F-statistic) & & & & \\
Durbin- & 1,7376 & & & \\
Watson stat & & & & \\
\hline
\end{tabular}

Nilai koefisien pengaruh ROA terhadap efisiensi sebesar 1,1213 , dengan nilai probabilitas $(0,0000)$. Nilai probabilitas lebih kecil dari alpha 5\%. Artinya, ROA berpengaruh signifikan terhadap efisiensi. Interpretasi koefisien regresi pengaruh ROA terhadap efisiensi adalah, kenaikan ROA 1 satuan menyebabkan peningkatan efisiensi sebesar 1,1213 satuan dengan asumsi cateris paribus.

Hasil ini sesuai dengan penelitian-penelitian di Indonesia yang dilakukan oleh Zamil dan Rahman (2007) yang membuktikan adanya hubungan positif antara ROA terhadap tingkat efisiensi. Penelitian ini juga sesuai dengan hasil yang dilakukan oleh Gupta et al.(2008) serta Kaur dan Kaur (2013). Hubungan antara ROA dan tingkat efisiensi yang positif dijelaskan oleh Blaug (2001) yang menyatakan bahwa efisiensi digerakkan oleh kekuatan struktur pasar, Blaug menyatakan dengan "competition as a process of rivalry". Tingkat efisiensi yang lebih tinggi dari suatu perusahaan akan menghasilkan tingkat keuntungan yang besar pula. Struktur pasar yang terkonsentrasi pada beberapa perusahaan tertentu menyebabkan pangsa pasarnya lebih besar dengan kondisi pasar yang dinamis memberikan keuntungan yang lebih besar.

Nilai koefisien pengaruh ROE terhadap efisiensi sebesar 0,4811 , dengan nilai probabilitas $(0,0263)$. Nilai probabilitas lebih kecil dari alpha 5\%. Artinya, ROE berpengaruh signifikan terhadap efisiensi. Interpretasi koefisien regresi pengaruh ROE terhadap efisiensi adalah, kenaikan ROE 1 satuan menyebabkan peningkatan efisiensi sebesar 0,4811 satuan dengan asumsi cateris paribus. Hasil ini sesuai dengan penelitian Fathoni (2012) bahwa ROE berpengaruh positif signifikan terhadap efisiensi dan juga penelitian Mawardi (2005) yang menyimpulkan bahwa tingkat efisiensi perusahaan (bank) berpengaruh negatif terhadap kinerja bank yang diproksikandengan ROE.

Koefisien dummy sebesar $-0,2879$ dengan nilai probabilitas $(0,0000)$. Nilai probabilitas lebih kecil dari alpha 5\%. Artinya, dummy berpengaruh signifikan terhadap efisiensi. Nilai koefisien -0,2879. Artinya perbedaan rata-rata efisiensi sebelum adanya kebijakan ekspansi dan setelah adanya kebijakan ekspansi sebesar 0,2879, tanda negatif mengindikasikan bahwa rata-rata efisiensi sebelum kebijakan ekspansi lebih tinggi dibandingkan rata-rata efisiensi setelah adanya kebijakan ekspansi.

Hasil uji-F diperoleh nilai f hitung sebesar 3.3944 dengan nilai probabilitas $(0,0168)$. Nilai probabilitas lebih kecil dari alpha 5\%. Artinya, model regresi berganda sudah mampu menjelaskan keragaman efisiensi. Besarnya nilai R-square adalah 15,25\% artinya keragaman yang dijelaskan oleh faktor-faktor dalam model sebesar $15,25 \%$ sedangkan sisanya dijelaskan oleh faktor lain diluar model. Keterbatasan ketersediaan data menyebabkan hanya tiga variabel independen yang digunakan dalam model. Relatif sedikitnya variabel independen tersebut menyebabkan nilai koefisien determinasinya relatif kecil. 


\section{Implikasi Manajerial}

Dari hasil penelitian pada perusahaan PT.Dian Swara secara keseluruhan didapat beberapa temuan-temuan utama dan implikasi manajerial diantaranya bahwa efisiensi perusahaan dari periode 2009 sampai dengan 2014 mengalami siklus yang fluktuatif dan hasil secara keseluruhan tidak ada yang mencapai nilai efisiensi 1,00. Mengacu pada kondisi tersebut, dari sisi owner harus melihat secara jeli dan mengantisipasi langkahlangkah kedepan didalam mengelola perusahaan, agar laba perusahaan dapat lebih ditingkatkan dengan cara menganalisis komponen-komponen biaya dan pendapatan perusahaan secara mendalam. Adapun langkah-langkah yang diterapkan yaitu dengan melakukan analisis perkembangan perusahaan dalam lima tahun kedepan, melaksanakan tata kelola perusahaan dengan baik dan menerapkan serta menjalankan nilai-nilai perusahaan. Hasil perhitungan analisis regresi maka ROA dan ROE dari periode 2009 sampai dengan tahun 2014 memiliki pengaruh signifikan terhadap nilai efisiensi. Dari hasil analisis, terjadi hubungan yang positif antara ROA dan ROE terhadap efisiensi. Oleh sebab itu, pihak manajemen dapat melihat dari kedua variabel tersebut dan melakukan pengelolaan perusahaan dalam meningkatkan ROA dan ROE, serta menjalankan langkah-langkah yang telah menjadikan komitmen bersama untuk perbaikan dan kemajuan perusahaan.

\section{KESIMPULAN DAN SARAN}

\section{Kesimpulan}

Penelitian ini melakukan perhitungan terhadap kinerja efisiensi pada PT. Dian Swara selama periode 2009 sampai 2014 dan langkah pertama yang dilakukan adalah mengukur tingkat efisiensi perusahaan dengan menggunakan DEA, hasilnya menunjukan bahwa selama periode 2009-2014 tidak ada yang mendapatkan nilai 1,00. Namun, jika ditarik suatu kesimpulan bahwa pada tahun 2013 rata-rata nilai efisiensi sebesar 0,98, dan tahun ini dianggap lebih efisien jika dibandingkan terhadap tahun-tahun yang lainnya. Sedangkan tahun yang inefisien adalah tahun 2012 dengan rata-rata nilai efisiensinya sebesar 0,71 . Hal ini disebabkan tingginya biaya-biaya didalam kegiatan operasionalnya. PT. Dian Swara dalam menjalankan operasional perusahaannya harus memilah secara detail dan menganalisis komponen biaya-biaya dan pendapatan. Biaya-biaya mana saja yang harus di reduce dan juga adanya upaya perbaikan yang konsisten didalam meningkatkan pendapatan sehingga berpengaruh terhadap laba perusahaan.

Hasil analisis regresi linier berganda, yaitu ROA dan ROE yang berpengaruh signifikan positif terhadap efisiensi maka perusahaan harus meningkatkan variabel independennya yaitu ROA dan ROE sehingga efisiensi serta profit perusahaan dapat tercapai, dan untuk perhitungan pada variabel dummy, yaitu kebijakan sebelum dan sesudah melakukan ekspansi pada diversifikasi usahanya, diperoleh bahwa pada periode tahun 2009 sampai dengan tahun 2011, perusahaan lebih efisien jika dibandingkan pada periode tahun 2012 sampai dengan tahun 2014.

\section{Saran}

Meningkatkan pendapatan perusahaan serta melakukan efisiensi biayanya sehingga laba perusahaan dapat meningkat dengan memperhatikan pergerakan ROA dan ROE secara bulanan dan mengawasi jalannya perusahan secara maksimal. Melakukan analisis kelayakan serta skala optimal yang cermat sebelum dilakukan ekspansi pada diversifikasi bidang usahanya sehingga persoalan yang dihadapi saat ini tidak terjadi dimasa yang akan datang, dan juga menerapkan skala ekonomi yang ideal atau suatu batas minimum bagi industri untuk beroperasi secara ekonomis dan menguntungkan untuk kelanjutan perusahaan.

\section{DAFTAR PUSTAKA}

Abri AG, Mahmoudzadeh M. 2014. Impact of information technology on productivity and efficiency in iranian manufacturing industries. Journal of IndustrialEngineering International 11(1): 143-157.

Blaug M. 2001. Is competion such a good thing? Static Efficiency versus Dynamic Efficiency. Review of industrial organization. 19: 37-48.

Coelli TJ, Prasada RDS, O'Donnell CJ, Battese GE. 2005. Data Envelopment Analysis. An Introduction to Efficiency and Productivity Analysis. 2nd Ed. New York: Springer Science \& Business Media

Fathoni M. 2012. Estmasi dan faktor-faktor yang memengaruhi efisiensi bank domestik dan Bank Asing Di Indonesia. Jurnal Keuangan dan Perbankan 16(2). 
Firdaus, FM, Hosen MN. 2013 Efficiency of islamic banks using two stage approach of data envelopment analysis. Buletin Ekonomi Moneter dan Perbankan. 16(2): 155-176.

Gupta, Omprakash K, Yogesh D, Aneesh C. 2008 Dynamics of productive efficiency of Indian banks. International Journal of operations research 5(2):78-90.

Hartono, Imam, Djohar S, Daryanto HK. 2008. Analisis efisiensi bank perkreditan rakyat di wilayah Jabodetabek dengan pendekatan data envelopment analysis. Jurnal Manajemen \& Agribisnis 5(2): 52-63.

Kader HA, Adams M, Hardwick P. 2010. The cost efficiency of takaful insurance companies. Geneva Papers on Risk \& Insurance 35(1):161181.

Kaur P, Kaur G. 2013. A study of cost efficiency of indian commercial banks an impact of mergers. African Journal of Business Management 7(15): 1238-1249

Lazaridis, Tryfonidis. 2006. The relationship between working capital management a n d profitability of listed companies in the Athens Stock Exchange. Journal of Business Finance \& Accounting 19(1): 1-12

Mahdavi G, Moghaddam AG, Alipour S. 2012. An investigation of cost, revenue andprofitefficiency: The case of iranian companies. African Journal of Business Management. 6(30): 8879-8888.

Mawardi W. 2005. Analisis faktor-faktor yang memengaruhi kinerja keuangan bank umum di Indonesia. Jurnal Bisnis Strategi 14(1): 8394.

Miller SM, Noulas AG. 1996. The technical efficiency of large bank production. Journal of Banking and Finance 20: 495-509
Nazir MS, Alam A. 2010. The impact of financial restructuring on the performance of pakistani banks: A DEA approach. IUP Journal of Applied Finance 16(1): 71-86.

Ping-wenL.2002.Costefficiencyanalysis ofcommercial bank mergers in Taiwan. International Journal of Management 19(3): 408-417.

Raheman A, Nasr M. 2007. Working capital management and profitability-case of Pakistani firms. International Review of business research papers 3(1): 279-300

Sari SW, Nurmalina R, Setiawan B. 2014. Efisiensi kinerja rantai pasok ikan lele di Indramayu, Jawa Barat. Jurnal Manajemen \& Agribisnis 11(1):12-23.

Sawir A. 2001. Kinerja keungan dan Perencanaan Keuangan Perusahaan. Ed. ke-1. Jakarta:Pt. Gramedia Pustaka Utama

Sfinga I, Niklis D. 2011. Evaluation of bank efficiency with the dea approach: a comparisonof european commercial banks. Journal of computational optimization in economics and finance 3(2): 115-131.

Sharaf, FR, Haddad FS. 2015. the relationship between working capital management and profitability for industrial companies listed in amman stock exchange. Jordan Journal of Business Administration 11(2).

Sutawijaya A, Lestari EP. 2009. Efisiensi teknik perbankan Indonesia pasca krisis ekonomi: Sebuah studi empiris penerapan Model DEA. Jurnal Ekonomi Pembangunan 10(1): 49-67.

Zamil NAM, Rahman ARA. 2006. Efficiency of islamic and conventional commercial banks in Malaysia: A Data Envelopment Analysis (DEA) Study [Paper]. Malaysia: Institute of Islamic Banking and Finance (IIiBF). 